Danko Zelić

Institut za povijest umjetnosti, Zagreb

\author{
Ivan Viđen
}

Samostalni istraživač, Dubrovnik

\title{
Inventario dela giexia di S. Maria Mazor, de tute le argentarie, aparati deli sazerdoti, insenarii, libri, tapezarie et altre robe (1531.) - najstariji imovnik liturgijske opreme, ruha i paramenata dubrovačke prvostolnice
}

\author{
Izvorni znanstveni rad - Original scientific paper \\ Primljen - Received 15. 6. 2018. \\ UDK 271.5:726(083.82)](497.5Dubrovnik)"15"
}

DOI 10.31664/ripu.2018.42.02

\begin{abstract}
Sažetak
U radu se predstavlja i u cijelosti objavljuje dosad nepoznat inventarni popis liturgijske opreme, ruha i paramenata dubrovačke katedrale Gospe Velike (Sv. Marije Velike), pohranjen u Arhivu Biskupije dubrovačke. Sastavljen 1531. godine, Imovnik je podijeljen na šest cjelina (srebrninu,
\end{abstract}

komplete misnog ornata, misnice, plašteve, predoltarnike te ostale tekstilne predmete), a u njemu su naknadno evidentirani i predmeti kojima je imovina prvostolnice nadopunjavana do 1575. godine.

Ključne riječi: Dubrovnik, katedrala Gospe Velike, 16. stoljeće, popis, inventar

U Arhivu Biskupije dubrovačke odnedavno je pohranjen sveščić s popisom liturgijskog inventara, ruha i paramenata prvostolne crkve Gospe Velike (Sv. Marije Velike) iz 1531. godine (dalje: Imovnik), ${ }^{1}$ sačuvan u ostavštini dubrovačkog povjesničara Antuna Vučetića (1845.-1931.). ${ }^{2}$ Posrijedi je uistinu iznenađujuće otkriće jer se taj dokumentarni izvor, koliko nam je poznato, u historiografiji ne spominje. Stariji povjesničari dubrovačke Crkve možda su ga i poznavali, no kada je riječ o dragocjenostima katedrale, pozornost im je, od Serafina Cerve naovamo, bila zaokupljena poglavito relikvijarima sa svetim moćima.

Novootkriveni Imovnik najstariji je do danas poznat cjeloviti popis liturgijske opreme, ruha i paramenata dubrovačke prvostolnice, ali i jedini takav izvor iz vremena prije Velikog potresa. Budući da su u njemu između 1532. i 1575. evidentirani i novi predmeti, Imovnik je bio u uporabi gotovo pola stoljeća, najmanje još dvije godine poslije nastanka dosad najstarijega poznatog teksta s vijestima o liturgijskim predmetima i ruhu dubrovačke prvostolnice - zapisnika apostolskog pohoda biskupa Giovannija Francesca Sormanija iz 1573. godine. ${ }^{3}$

Svrha je ovog rada predstaviti strukturu, sadržaj i svojstva Imovnika iz 1531. godine te donijeti transkripciju njegova teksta. $^{4}$

\section{Opis i sadržaj sveščića}

Sveščić s Imovnikom formata je $26,5 \times 19,5 \mathrm{~cm}$. Sastavljen je od šest napola presavinutih i na hrptu koncem prošivenih komada pergamene, što znači da je izvorno imao dvanaest listova. Folijacija unesena u vremenu nastanka temeljnoga popisa arapskim brojevima (1-9) u gornjem desnom uglu listova obuhvaća samo ispisane listove; započinje na trećem 


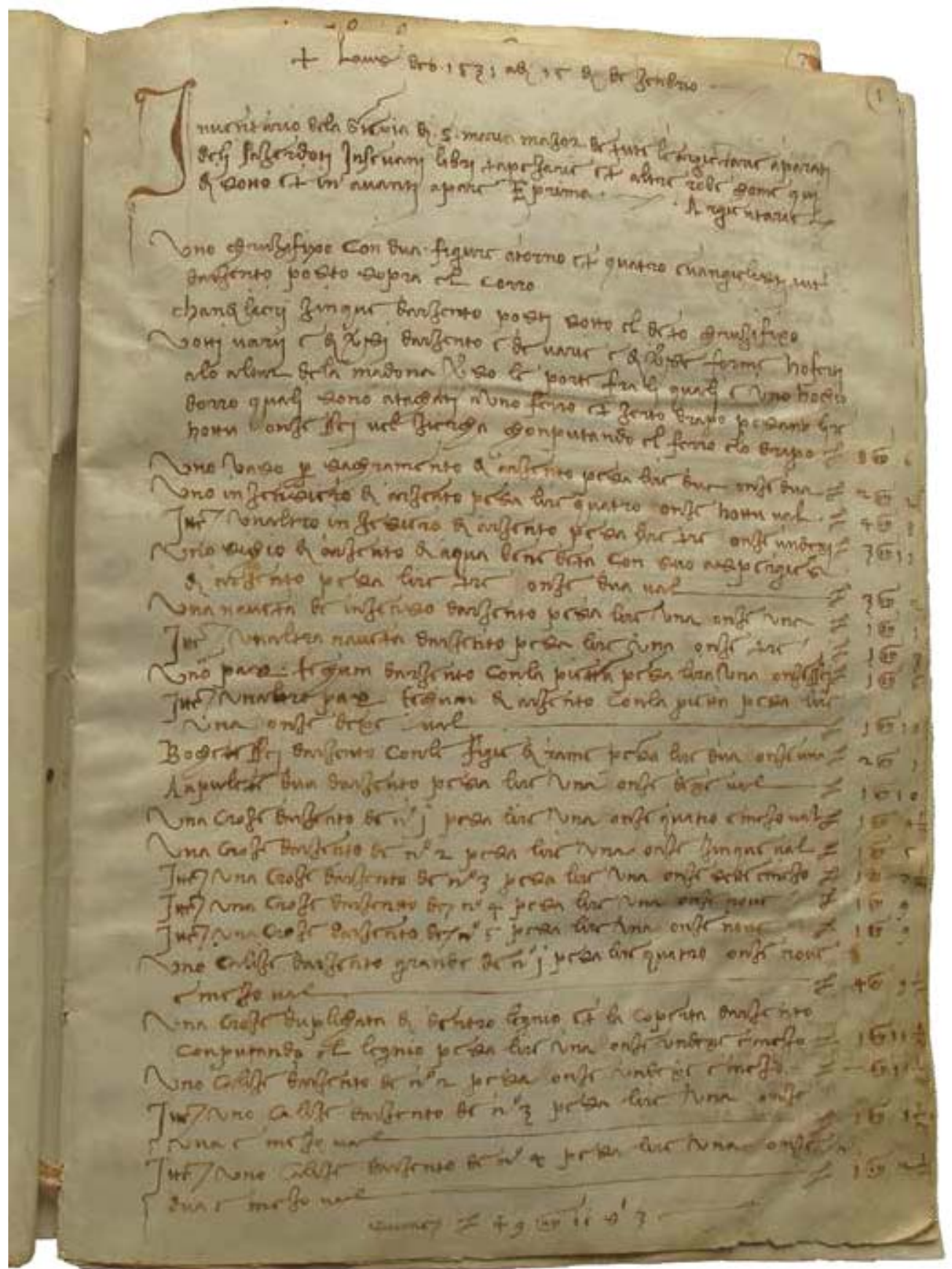

1. Imovnik dubrovačke prvostolnice Gospe Velike iz godine 1531., f. 1r

Inventory of the Cathedral of the Assumption of the Virgin in Dubrovnik from 1531, f. 1 r

i završava na jedanaestom listu. Posljednji, dvanaesti, list nažalost nije sačuvan.

Imovnik je sastavljen na talijanskom jeziku s primjetnim 'tragovima' latinskog, što se ogleda ponajprije u oblicima i tvorbi riječi, ali i u sintaksi zapisa. Temeljni popis, iz 1531. godine, ispisan je istom rukom, dočim naknadni upisi odaju nekoliko različitih rukopisa.

Na naslovnoj stranici sveščića je kristogram $(I H S)$. Drugi je list prazan, a popisi predmeta započinju na licu trećeg lista (f. 1r). Pri vrhu mu je znak križa, zatim invokacija Laus Deo, kojoj slijede nadnevak (1531, adi 15 di dezenbrio) i naslov:
Inventario dela giexia di S. Maria Mazor de tute le argentarie, aparati deli sazerdoti, insenarii, libri, tapezarie et altre robe. Imovnik je podijeljen na šest cjelina (rubrika). U prvoj, naslovljenoj Argentarie (srebrnina), na tri i pol stranice (ff. 1r-2v), popisani su predmeti od dragocjenih materijala, uglavnom srebra. Slijede im tekstilni predmeti, razvrstani na misne ornate (Aparati deli sazerdoti; f. 4r), misnice (Planete; f. 6r), plašteve (Pluviali; f. 7r) i predoltarnike (Pallii; f. 8r), a u posljednjoj su skupini utilitarni predmeti od tkanine (Tapeti e razi; f. 9r).

Po općem izgledu i vlastitoj numeraciji listova sveščića evidentno je da Imovnik nije fragment neke veće cjeline, nego 
samostalan dokument, zamišljen da kao glavni (matični) popis liturgijske opreme katedrale ostane u uporabi dulje vrijeme. Osim izbora trajnijeg materijala (pergamene, a ne papira) kao podloge za pisanje, na takav zaključak upućuju i prazni prostori ostavljeni između pojedinih rubrika (ff. $4 \mathrm{v}-$ $5 \mathrm{v}, 6 \mathrm{v}, 7 \mathrm{v}, 8 \mathrm{v}, 9 \mathrm{v})$, predviđeni za upisivanje novih predmeta.

S obzirom na sadržaj, prije svega treba upozoriti na činjenicu da Imovnikom nisu obuhvaćene sve dragocjenosti dubrovačke prvostolnice. U njemu, naime, izostaju relikvijari sa svetim moćima koji su se u Dubrovniku čuvali odvojeno od liturgijske opreme (u katedralnom moćniku) i bivali periodično popisivani u zasebnim inventarnim popisima. Imovnik, nadalje, ne uključuje ni kultne predmete od plemenitih kovina, poput srebrnih poliptiha (na glavnom oltaru i oltaru sv. Križa), ni stalnu liturgijsku opremu katedralnih oltarā (kao što su par kandila s vječnim svjetlom na glavnom oltaru, svijećnjaci, koji će se javiti tek u upisima unesenim poslije 1531., ili zvonca). Neki su kultni predmeti, primjerice dvije glasovite Gospine ikone čašćene u katedrali, zabilježeni neizravno; evidentirani su njihovi ukrasi, nakit i poklonjeni im zavjetni darovi.

\section{Struktura zapisa}

Unutar pojedinih rubrika na zasebnim je pozicijama najčešće registriran po jedan, rjeđe dva ili više predmeta (kada su posrijedi bili parovi, kompleti ili skupine), primarno identificiranih nazivima te materijalima od kojih su bili izrađeni. Za gotovo sve predmete u rubrici Argentarie zabilježena je težina, a za crkveno ruho i paramente boja te tehnika izrade. Mnogi se predmeti, k tome, opisuju i pobliže - bilježenjem svojstava kojima su se među sličnim (istoimenim) predmetima bili isticali ili se pak od njih razlikovali, u prvom redu veličinom, oblikom ili tehnikom izrade, potom motivima, vrstama i tehnikama ukrašavanja te, u pojedinim slučajevima, i ikonografijom figuralnih ukrasa.

Brojniji istovrsni liturgijski predmeti, poput križeva ili kaleža, te kompleti ruha i paramenata distingvirani su rednim brojevima. Kod tekstilnih je kompleta, primjerice misnih ornata, ili zbirno popisanih skupina predmeta evidentiran i broj dijelova, a osim u tekstu sve su brojčane vrijednosti zapisane i u odvojenim stupcima, na desnim marginama stranica.

U transkripciji Imovnika u prilogu ovog rada, svakom od ukupno 151 zapisa (pozicije) prethodi redni broj, pridodan radi lakšeg snalaženja. Kako bi se istaknulo da ne pripadaju tekstu izvornika, ti su brojevi - kako u prijepisu, tako i unutar ovog teksta - stavljeni u uglate zagrade. Numeracija pozicija u prijepisu je kontinuirana i u jedinstvenom slijedu obuhvaća zapise $\mathrm{u}$ temeljnom popisu (sastavljenu pod nadnevkom 15. prosinca 1531.) i one koji su u rubrikama dodavani naknadno. Brojevi u ovom tekstu s predznakom »br.« odnose se na rastuće (redne) brojeve kojima je istovrsne predmete radi razlikovanja, kao što je već spomenuto, označavao sam sastavljač - primjerice križeve (od croze ... de numero 1 do croze ... de numero 9) ili kaleže (od calize ... de numero 1 do calize ... de numero 20).

\section{Temeljni popis (1531.)}

\section{Srebrnina (Argentarie)}

U prvoj, ujedno i najopsežnijoj rubrici, pod naslovom $A r$ gentarie godine 1531. na sedamdeset je pozicija ([1]-[70]) ukupno popisano više od $115,{ }^{5}$ najvećim dijelom srebrnih predmeta. Težine su im iskazane slovima, a potom i brojevima u standardnim dubrovačkim zlatarskim mjernim jedinicama - librama, uncama i heksagijama ${ }^{6}$ - a pri dnu stranica zapisane su i zbirne vrijednosti. Zabilježbe o težini izostaju kod predmeta koje popisivaču iz nekog razloga nije bilo moguće izvagati, najčešće stoga što su mu bili izvan dosega, zatim kod predmeta koji nisu bili od plemenitih kovina te kod predmeta koji su bili pohranjeni u katedrali, ali nisu bili njezino vlasništvo.

Na prvom je mjestu popisa monumentalna kompozicija reljefnih srebrnih skulptura ovješenih iznad korske pregrade - trodijelna skupina Raspeća ispod koje su se nalazili likovi četvorice evanđelista [1] te pet visećih kandila [2]. Slijedi zapis o srebrnim zavjetnim darovima (pločicama od iskucanoga srebrnog lima) Gospi od Porata [3] koji se bilježe zbirno, kao "različiti zavjeti različitih vrsta, među kojima i jedno zlatno oko «, a neposredno potom zabilježena je srebrna posuda za Presveti oltarski sakrament (vaso per sachramento) [4].

Najzastupljenije su vrste predmeta u rubrici Argentarie križevi i kaleži. Godine 1531. popisano je ukupno trinaest križeva. Zajednički im se, generički naziv (croze ili croce) odnosio, međutim, na predmete različitih dimenzija i namjena. Za pet manjih srebrnih križeva (br. 1-5) [14-18] ne bilježe se nikakve druge pojedinosti osim težine (između 1 i 2 libre), pa je stoga to i jedina indicija o njihovoj svrsi; najvjerojatnije je riječ o križevima koji su se postavljali na oltare tijekom bogoslužja. Podrobnije se opisuju dva srebrna »križa s raspećem « (križevi br. 6 i 7) - prvi [48] s likom sv. Petra, a drugi [50] s Bogorodicom na reversu - koji su, s obzirom na težinu (3:11, odnosno 3:2 libre), nedvojbeno služili kao procesijski (ophodni) križevi.

Pri kraju popisa zabilježeni su, bez podataka o težini, i jedan bakreni pozlaćeni (br. 8) [51] te dva željezna križa - križ br. 9 »s grčkim slovima« [52] te još jedan (bez rednog broja) što ga se »običavalo nositi iza pokojnika« [59].

Spomenutih devet križeva označenih rednim brojevima bili su, kako se čini, u liturgijskoj uporabi, bilo kao oltarski ili procesijski križevi. Od inih je u popisu zabilježen i jedan "udvojen «, tj. dvostruki (patrijarhski) križ [20], a pozornost privlači i »veliki križ s krunom« [53]. Zapisujući njegovu težinu (6 libara srebra), sastavljač Imovnika poziva se na "prosudbu majstora«, što znači da je taj predmet najvjerojatnije bio ovješen negdje u prostoru katedrale, možda iznad oltara sv. Križa. ${ }^{7}$ Posljednji križ zabilježen u popisu je "srebrni križ na štapu koji se nosi pred nadbiskupom « [69].

Godine 1531. u katedrali je popisano ukupno dvadeset srebrnih kaleža. Poput križeva, obilježeni su rednim brojevima. Kalež br. 1, ujedno najveći [19], težio je gotovo 5 libara, kalež br. $10(X)$ bio je upola lakši [33], dočim se težina sedamnaest manjih, označenih brojevima od 2 do 9 i od 
11 do 19 [21-25; 30-32, 34-42] kretala između 1 i 2 libre. Na zasebnoj je poziciji [29] zbirno zabilježeno i osamnaest patena (plitica) koje su s isto toliko popisanih kaleža činile komplete - dvije s velikim, a ostale s manjim kaležima. Posljednji registriran, kalež s patenom br. 20 [43], nije izvagan jer je bio nadbiskupov.

Od standardnih srebrnih liturgijskih utenzilija u popisu se javljaju tri kadionice (inzensiero) $[5 ; 6 ; 54]$ ), dvije tamjanice/ navikule (naveta) [8; 9], par žličica za tamjanice (chuchiare dua ... per le navette de inzensio) [49], dva kompleta od po dvije ampulice (anpulete), tzv. gostarice, za misnu vodu i vino $[13 ; 47]$ te šest bočica (bochete) [12]. Od 'svetoga posuđa' katedrala je, uz već spomenutu posudu (vaso) za Presveti oltarski sakrament [4], posjedovala i komplet triju krizmarija, tj. velikih posuda (charafe) za sveta ulja [26], četiri čestičnjaka/ pikside (busulo) [55-58]), kotlić za blagoslovljenu vodu sa škropilom (sichio con suo aspergile) [7] te veliki vrč (bochal grande) [45] i zdjelu/umivaonik (bazil) [46] koji su zacijelo služili za abluciju, tj. obred pranja ruku. Evidentirana su i dva oskulatorija (predočnice, pacifikala), koje sastavljač bilježi latinskim imenom pax techum $[10 ; 11]$, te veliko srebrno svetohranište (tabernachulo per Corpus Christi) [60].

Pokretna imovina prvostolne crkve obuhvaćala je i nekoliko predmeta koji se ubrajaju u pontifikalne insignije: štap (pastoral) [28], pektoral, tj. križ na lančiću (croze pichula darzento con la catena darzento per mon signor) [62], te prsten (anelo epischopale) [63].

Od neliturgijskih srebrnih predmeta zabilježeno je osam 'igala' (agii) nekog (nespecificiranoga) križa [61], ${ }^{8}$ te jedan predmet (forfeta) nepoznate namjene [67]. ${ }^{9}$

Popis srebrnine obuhvaća i (odvojive) srebrne ukrase predmeta zabilježenih u drugim rubrikama - tri svilene kuglice (pomi con bottoni) sa srebrnim privjescima ukrašenim zlatnim filigranom (lavorati al filo; oro filato) koje su pripadale kapuljačama pluvijala [27] te srebrne oplate korica (choverte) dviju liturgijskih knjiga $[44 ; 68]$.

Pri kraju rubrike zabilježene su dvije desetokrake srebrne krune s draguljima $[64 ; 65]$ - nakit jedne od dviju u katedrali čašćenih Gospinih ikona (čini se, one iza glavnog oltara). Ukrasi tih kruna, od biserja sa srebrnim privjescima, registrirani su na zasebnoj poziciji [66].

Svrha Imovnika nije bila samo popisati predmete, nego i evidentirati njihovu vrijednost; materijali od kojih su predmeti bili izrađeni bilježeni su stoga vrlo pomno. Među predmetima u cijelosti načinjenima od srebra, koji, dakako, čine dominantnu skupinu, moguće je jasno razabrati one izrađene (i) od drugih materijala. Primjerice, štap pastorala [28] imao je drvenu jezgru, a drvene su konstrukcije, s oplatom od srebrnog lima, bili i dvostruki patrijarhski [20] te jedan od dvaju procesijskih križeva [50]. U svim takvim slučajevima težina predmeta bilježi se uz odgovarajuću napomenu (conputando el legnio), a u težinu posljednjega spomenutog križa osim drva uračunat je i bakar od kojega je vjerojatno bio načinjen njegov stalak. Bakrene su dijelove imali i neki predmeti liturgijskog posuđa, primjerice šest srebrnih bočica »s bakrenim drškicama« (con le figie di rame) [12], a od istog su materijala bila načinjena i podnožja dviju piksida/čestičnjaka [55; 56]. Za križ »koji se nosi pred nadbiskupom « [69] ne bilježi se da je imao drvene dijelove, ali taj predmet iz nepoznatih razloga nije ni izvagan. Zabilježena težina zavjetnih darova Gospi od Porata [3] uključuje i težinu željezne, tkaninom obložene konstrukcije na koju su bili pričvršćeni.

Naslov Argentarie je, dakle, generički; predmeti okupljeni u toj skupini nisu bili načinjeni isključivo od srebra, štoviše ni od metala. Ne-srebrni metalni predmeti, poput spomenutih križeva od željeza i pozlaćenog bakra, javljaju se pri kraju rubrike, a temeljni popis srebrnine zaključen je bisernom mitrom [70] koja je pripadala nadbiskupu.

\section{Misni ornati (Aparati deli sazerdoti)}

Pod naslovom Aparati deli sazerdoti na deset je pozicija [84-93] godine 1531. popisano deset misnih ornata koji su se sastojali od ukupno 85 komada odjeće i opreme. Svaki je komplet (u izvorniku zvan capela) identificiran rednim brojem, bojom i vrstom materijala, ${ }^{10}$ potom se poimenično nabrajaju svi sastavni dijelovi te na kraju bilježi njihov ukupan broj. Podaci o boji i vrsti tkanine, gdjekad i ukrasa, odnose se, po svemu sudeći, na plašteve i/ili misnice.

Najraskošniji i najbogatiji misni ornat u posjedu prvostolnice - bijela capela od zlatne tkanine [84] - sastojao se od 18 dijelova: plašta (pluviale), misnice (planeta), kratke tunike (streta), ${ }^{11}$ dalmatike (dalmatica), tri košulje (camixi), štole (stola), tri manipula (manipuli), tri pozlaćena, izvezena i biserjem ukrašena naglavnika/humerala (amichti), te tri crvena svilena pojasa (zenture) sa zlatnim kopčama. Četiri ornata imalo je između 11 i 15, a pet jednostavnijih samo po tri dijela - misnicu, kratku tuniku i dalmatiku.

\section{Misnice (Planete)}

U temeljnom je popisu evidentirano 16 misnica [94-108], identificiranih rednim brojevima te vrstom tkanine, ${ }^{12}$ bojom i ukrasom. Sve su misnice na prednjoj ili na objema stranama imale aplicirane križeve, izvedene u raznim tehnikama: izvezene (con la croze rechamata), reljefno istaknute (con la croze rilevata) ili izrađene posebnom vrstom zlatnih niti, tzv. kölnskim zlatom (lavorata con orro di Colognia). ${ }^{13}$

\section{Plaštevi (Pluviali)}

Godine 1531. popisano je šest plašteva [110-115] - tri od zlatne tkanine, dva od crvenog i jedan od ljubičastog baršuna, svi s bortama i kapuljačama ukrašenim vezom. Za svaki je plašt zabilježen i podatak o vrsti crvene tkanine od koje mu je bila načinjena podstava.

\section{Antependiji (Pallii)}

Na šesnaest pozicija [122-138] u rubrici naslovljenoj Pallii u temeljnom je popisu evidentirano 24 antependija. Posrijedi su uglavnom predoltarnici; za svaki se bilježi vrsta tkanine 
i boja, ${ }^{14}$ te motivi i vrsta ukrasa - uglavnom križeva, izvezenih ili apliciranih u različitim tehnikama, potom cvjetova te bogatih bordura. Jedan je antependij [123] bio ukrašen prizorom Navještenja, drugi likom Bogorodice [135], a za tri je antependija [135] zapisano tek da su imali izvezene likove, dakako svetaca, i križ od zlatne vrpce (chordela, churdola). Ukrasom se ističe predoltarnik br. 11, s križem od 24 mala srebrna medaljona te 37 većih srebrnih medaljona na obodu. Osim predoltarnikā, nazivom palio označavani su, međutim, i drugi, donekle srodni tekstilni predmeti, primjerice tkanina sjenila pod kojim se nosila euharistija (palio ... dela tenda de Corpus Cristi) [137], zabilježena kao posljednji predmet u ovoj rubrici.

\section{Sagovi i drugi tekstilni predmeti (Tapeti e razi)}

Pod naslovom Tapeti e razi na osam je pozicija [139-146] godine 1531. registrirano ukupno 32 komada neliturgijskih predmeta od tkanine, uglavnom podnih i zidnih obloga te pokrova. Bilježeni su u skupinama, i to prema namjeni. Kako se može zaključiti iz konteksta, naziv tapeti odnosio se na sagove - kojih je bilo ukupno trinaest; sedam novih, »običnih « [140], i šest trošnih [141] - ali i na tekstilne pokrove. Od tri »velika« [139], jedan se stavljao na klupu pred kneževim tronom, drugi na klupu pred oltarom sv. Ane, a treći na propovjedaonicu (ili stalak za čitanje propovijedi). U ovoj su rubrici, nadalje, zabilježene i četiri zidne zavjese od kože (spaliere) što su se »običavale vješati na zidove $\mathrm{u}$ svetištu « - dvije veće, oslikane, s Bogorodičinim likom [142], te dvije manje koje su se postavljale »iza leđa kanonika" [143], što najvjerojatnije znači iza korskih klupa. Charpeta je naziv za jednostavnije podne prostirače; na dvije pozicije [144; 145] popisano ih je ukupno jedanaest. Posljednji predmet zabilježen 1531. godine - kako u ovoj rubrici, tako i u Imovniku (u opsegu u kojem se sačuvao do danas) - bila je trošna tapiserija s figuralnim ukrasom (uno razo figurato frusto) [146].

\section{Dio koji nedostaje: liturgijske knjige}

$\mathrm{Na}$ to da je Imovnik obuhvaćao i popis liturgijskih knjiga prvostolnice, osim naslova sveščića, upućuju i već spomenuti zapisi u rubrici Argentarie - o koricama, tj. (odvojivim) srebrnim oplatama dvaju svezaka, evanđelistara [44] i »novog misala« [68] - gdje stoji da su same knjige evidentirane avanti, in lo aventario deli libri. Težinom od 8 libara i 5 unci korice misala ističu se kao najteži od svih izvaganih srebrnih predmeta. Popis knjiga zacijelo se nalazio na izgubljenom posljednjem (dvanaestom) listu sveščića.

\section{Obilježja temeljnog popisa}

Temeljnim je popisom sastavljenim potkraj 1531. godine ukupno obuhvaćeno više od 280 predmeta. Redoslijed njihova evidentiranja samo je u početnom dijelu Imovnika indikativan za mjesta na kojima su se predmeti nalazili. Popisivanje je nedvojbeno započelo u svetištu katedrale [1-4], dočim su se predmeti registrirani u nastavku prve rubrike (Argentarie) te u rubrikama Aparati deli sazerdoti, Planete i Pluviali čuvali u sakristiji. Istovrsni liturgijski predmeti od srebra, poput križeva ili kaleža, premda bilježeni u grupama, nisu okupljeni u konzistentne podskupine, što upućuje na pretpostavku da im je redoslijed u popisu odgovarao mjestima u sakristijskim ormarima. ${ }^{15}$

Obavijesti o specifičnoj svrsi ili načinu korištenja predmeta u Imovniku rijetke su. Od liturgijskih su predmeta u tom pogledu iznimke tek dvije ampulice (gostarice) »za glavni oltar« [47] te željezni križ koji se nosio »iza mrtvih« [59], a u popisu je jasno moguće razabrati i pontifikalne insignije. Mjesta, načini ili vremena uporabe (s obzirom na liturgijski kalendar) ne bilježe se ni za paramente i ruho.

Svrha zapisivanja podrobnijih podataka o oblicima, tehnikama izrade ili ukrasu bila je ponajprije olakšati razlikovanje pojedinačnih predmeta među onima istog naziva i/ ili namjene. Primjerice, za prvi od ukupno četiri popisana čestičnjaka (pikside) [55] zapisano je da ima bazu od bakra i križ na poklopcu, da je kvadratnog oblika i ukrašen emajliranim medaljonima (con tondeti xmaldati); za drugi [56], koji je također imao bakreno podnožje, tek da je okrugao (tondo); za treći [57] da je načinjen u tehnici granulacije (lavorato ali pometi) sa zvoncem te križem na poklopcu (con campanelo et con la croce di sopra), a za četvrti [58] da je bio narebrenih površina (lavorato ale sunde). ${ }^{16}$ Katkad se, međutim, podatak o tehnici izrade ili karakterističnom ukrasu bilježi i za jedine predmete svoje vrste. Primjerice, bokal [45] i zdjela [46] za obred pranja ruku ujedno su i jedini predmeti za koje je zapisano da su načinjeni u tehnici punciranja (lavorati al ponzon), a samo za »veliko srebrno svetohranište« [70] zabilježeno je da je bilo »s [gorskim] kristalom«. Kod liturgijskih predmeta koji su tvorili najbrojnije skupine - križeva i kaleža - obavijesti o tehnici izrade uglavnom izostaju, vjerojatno zato što se tim svojstvom nisu međusobno razlikovali, ${ }^{17}$ a moguće je da su bili i označeni (graviranim) brojevima, jednakim onima zapisanim u Imovniku.

$\mathrm{U}$ repertoaru ukrasnih motiva na tekstilnim predmetima najzastupljeniji su, dakako, križevi te cvjetovi, tj. cvjetni uzorci (fiori), na predoltarnicima i plaštevima ističu se »krune«, zacijelo njihove posebno ukrašene bordure, a na misnicama borte (frixi), najčešće zlatne. Misnica br. 3 od bijeloga damasta bila je ukrašena girlandom od zelene svile sa zlatovezom (con la festa romana di seta verde lavorata aposta dorro).

Kad je riječ o ikonografiji figuralnih ukrasa, osim viseće skupine reljefa (Raspeća s Bogorodicom i sv. Ivanom te likovima evanđelista) nad korskom pregradom i sv. Petra na naličju jednog ophodnog raspela, svi podaci te vrste u temeljnom se popisu odnose na Bogorodicu ili prizore iz Bogorodičine ikonografije. Reljefnim su prikazom Bogorodice sućutne ( $P i$ etta) bila ukrašena oba oskulatorija [10;11], a Bogorodičin je lik bio i na reversu drugog od dvaju evidentiranih ophodnih raspela [50] te, naslikan, na dva predoltarnika [123; 135], na prvom u prizoru Navještenja. I dva veća [142] od četiri kožnata zastora (spaliere) bila su oslikana, depinte con la 
Madona. Za neke se tekstilne predmete - tri predoltarnika $[122,124,127]$ i tapiseriju [146] - bilježi samo da su ukrašeni likovima (con le figure; figurato).

Podaci o vrsnoći izrade i provenijenciji predmeta u temeljnom popisu nisu odviše izdašni i vezani su isključivo uz utilitarne tekstilne predmete. Za sedam je sagova (tapeti) zabilježeno da su »obični« (di sorte comuna), a za devet prostirki (charpete) da su domaći proizvod (hopera di Raguxi). Naziv »aleksandrijske prostirke" (charpete lexandrine) mogao bi biti generički termin za specifičnu vrstu tekstila ili pak tip predmeta, ali ne treba isključiti ni mogućnost da je Aleksandrija bila mjesto njihova podrijetla ili kupnje. ${ }^{18}$

Na tekstilne se predmete odnose i sve zabilježbe o fizičkom stanju predmeta. U rubrikama koje obuhvaćaju crkveno ruho i paramente kao trošni izrijekom su opisani samo dva misna ornata $[90 ; 92]$ te jedan antependij [127] i tapiserija [146]. Riječima novi (novi), rabljeni (uxati) i trošni (frusti) podaci o stanju su, međutim, sustavno bilježeni za sve tekstilne predmete u posljednjoj rubrici, što je posve razumljivo zbog njihova utilitarnog karaktera i izloženosti habanju.

\section{Naknadni upisi (1532.-1575.)}

Poslije sastavljanja temeljnog popisa u Imovniku je na 24 pozicije registrirano još više od 45 predmeta. U tim zapisima susrećemo i vrste predmeta, primjerice svijećnjake, koji su u prvostolnici nedvojbeno postojali i u vrijeme sastavljanja temeljnog popisa, ali tada nisu evidentirani. Također, za razliku od temeljnog popisa, na više se pozicija bilježe imena osoba koje su novoregistrirane predmete prodale, darovale, oporukom ostavile, ili pak pribavile za prvostolnu crkvu, te podaci o provenijenciji pojedinih predmeta. Podaci o materijalima, težini i vrijednosti naknadno registriranih predmeta nisu, međutim, bilježeni toliko sustavno kao u temeljnom popisu.

U rubrici Argentarie na 12 je pozicija [ $71-81 ; 83]$, uz nepoznat broj votivnih darova [82], u sedam navrata dodano 25 predmeta. Prvi od tih zapisa unesen je svega pola godine poslije nastanka temeljnog popisa; dana 22. lipnja 1532. evidentirane su zlatna mitra i svilene pontifikalne rukavice [71] što ih je katedrali oporukom ostavio Rainaldo Graziani iz Cotignole ( $† 1529$.; dubrovački nadbiskup od 1510. do 1520. godine), ${ }^{19} \mathrm{a}$ u Dubrovnik donio njegov nećak Marko. Pod istim su nadnevkom registrirani i pozlaćeno srebrno svetohranište, po cijeni od 32 dukata kupljeno od (ili posredovanjem) Andrije Matkovića [72], te »kalež bez patene«, dar Frana Marinova Gozze [73]. Deset godina poslije zapisan je kalež s patenom koji je katedrali posljednjom voljom ostavio Đivo Paladinov Gondola [74]. Bio je od zlata, teži, što znači i veći od svih kaleža popisanih u Imovniku, a s obzirom na materijal izrade, dakako i mnogostruko vredniji. Godine 1544. popisu je dodana kruna postavljena na glavu Gospe od Porata [75], s napomenom da su drago kamenje kojim je bila ukrašena te dijelom i zlato od kojega je bila načinjena kupljeni novcem iz oporučnog legata Marije, udovice Marina Silvestrova Zamagna. Godine 1560. zabilježeni su kadionica »bez lađice« [76], deset srebrnih svijećnjaka dopremljenih iz Rima [77], tri zlatna lanca (catene) darovana Gospi od Porata [78], zlatna ogrlica (cholarino) s privjeskom s četiri bisera [79] te jedan fino izrađen zlatni lančić (chatenella sutil doro) [80], vrijedan "po prilici tri škude«.

Posljednji je datirani zapis u rubrici Argentarie (i u Imovniku uopće) - o dva svijećnjaka koje je iz Rima donio Đivo Marinov Gondola [81] - unesen 19. kolovoza 1575. godine. Poslije toga datuma istim su rukopisom, bez nadnevka (čini se još iste godine), na zasebnoj poziciji [82] zbirno zabilježeni zavjetni darovi od srebra »različitih i raznolikih oblika «, ukupne težine više od (doslovce: »dobre vage«) 3 libre, te nedovršeni zapis o još jednom lancu [83], možda također načinjenu od zlata.

U rubrici Aparati deli sazerdoti nakon 1531. godine nije bilo promjena.

U rubrici Planete za posljednju je zabilježenu misnicu - od bijelog brokata [109] - naknadno zapisano da je raskrojena i da su od nje načinjeni ukrasi za košulje. To je ujedno jedini predmet za koji je inventar katedrale tijekom vijeka uporabe Imovnika bio umanjen.

U rubrici Pluviali ubrzo poslije nastanka glavnog popisa, već sljedeće, 1532. godine, registrirano je pet novonabavljenih plašteva [116-120]. Srebrne kuglice (fiochi; 'cofovi') na njihovim kapuljačama tom su prigodom - za razliku od istovrsnih ukrasa starijih plašteva evidentiranih među srebrninom - zabilježene u istoj rubrici, na zasebnoj poziciji [121]; jedna od njih imala je privjeske izrađene od zlatnog filigrana (lavorati a oro fillato).

Jedini predmet naknadno, ali bez nadnevka, unesen u rubriku Pallii bio je pokrov za nadbiskupski tron od satena grimizne boje [138].

Naposljetku, u posljednjoj je rubrici - Tapeti et razi - u pet navrata između 1538. i 1564. godine evidentirano trinaest novih sagova [147-151]; za jedan je zabilježeno da su ga darovale dubrovačke vlasti.

\section{Kraj uporabe Imovnika}

Spomenuti nadnevak posljednjega datiranog zapisa - 19 . kolovoza 1575. - ujedno je i terminus a quo za prestanak vijeka uporabe Imovnika. Do tog je vremena u sveščiću na 151 poziciji ukupno popisano više od 325 predmeta; točan im broj nije moguće utvrditi budući da su votivni darovi (u dva navrata) zabilježeni zbirno $[3 ; 82]$.

\section{Sudbina liturgijske opreme, ruha i paramenata popisanih u Imovniku}

U potresu 1667. godine liturgijska srebrnina dubrovačke katedrale nedvojbeno je stradala znatno više od relikvijara. Premda nepopravljivo oštećena, prvostolnica tada ipak nije, kako se nerijetko piše, »srušena do temelja «, ali je teško vjerovati da je njezina sakristija - dograđena uz sjeverno bočno 


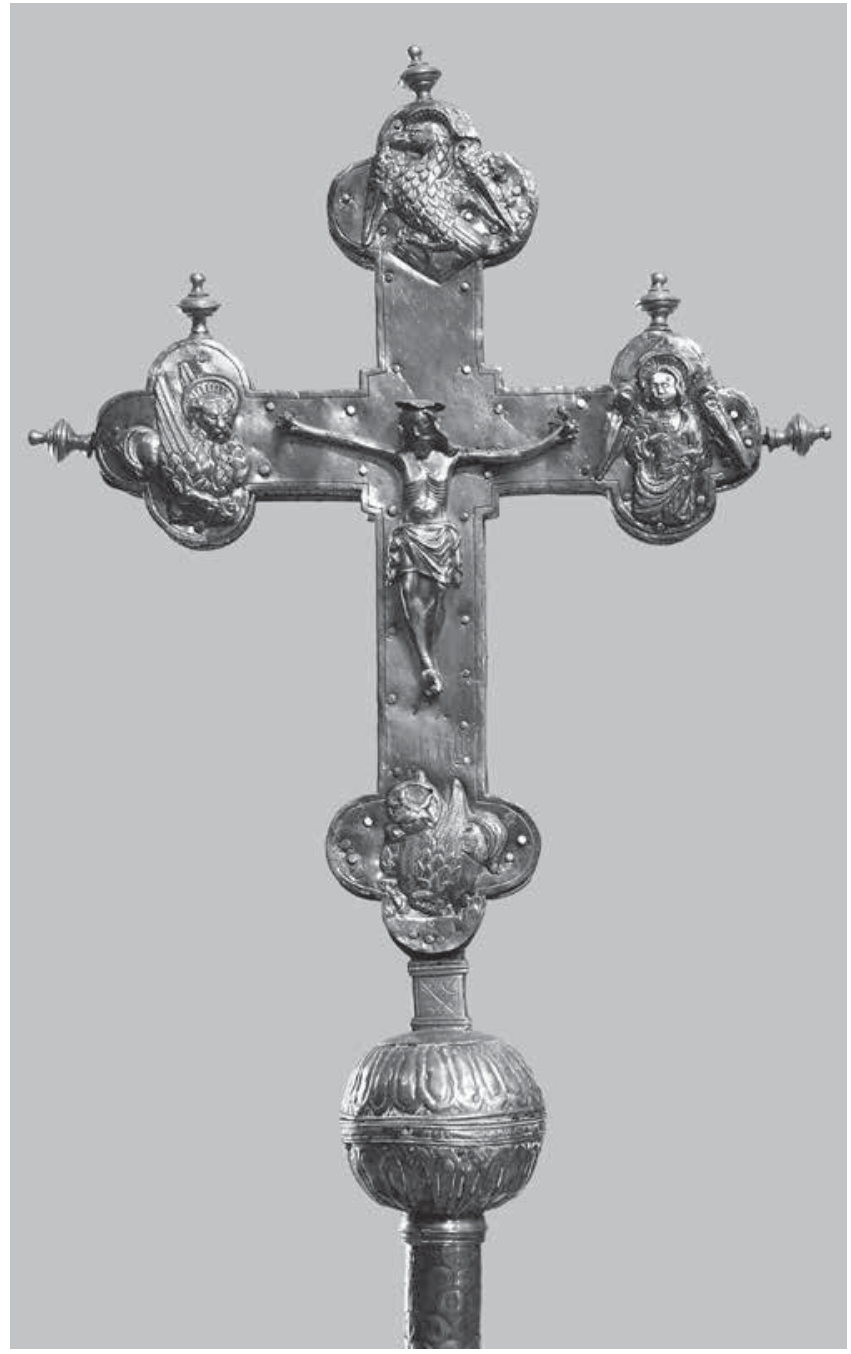

2. Metropolitski križ s natpisom dubrovačkog nadbiskupa Rainalda Grazianija i katedralnih prokuratora iz godine 1516.

Metropolitan cross with an inscription of Dubrovnik Archbishop Rainaldo Graziani and procurators of the cathedral from 1516

pročelje između 1442. i 1445. (prema projektu Petra Martinova iz Milana) i oslonjena na dva stupa - izdržala potres.

Dragocjeni predmeti od plemenitih kovina ubrzo su izvučeni iz ruševina, a već 1669. godine opat Stjepan Gradić javlja Senatu Republike kako je uspio ishoditi papinsko dopuštenje da se srebrnina upotrijebi za gradnju nove prvostolnice. ${ }^{20}$ Sudimo li po današnjem katedralnom inventaru, to se zacijelo nije odnosilo na relikvijare, nego poglavito na liturgijsku opremu i kultne predmete. Njihovi su ostaci, međutim, zajedno s relikvijarima čuvani još desetljećima; definitivna je odluka da se "polomljeno srebro « stare katedrale pretopi i da se dobiven novac uloži u opremanje novog zdanja donesena tek 1711. godine. ${ }^{21}$

Od ruha katedrale iz vremena prije velikog potresa u današnjem zdanju, dakako, nije sačuvano ništa, ${ }^{22}$ a liturgijskih je predmeta tek nekoliko. Izdvoje li se artefakti koji su nekoć pripadali drugim gradskim crkvama, predmeti za koje postoji mogućnost da su se u katedrali nalazili u 16. stoljeću, odnosno $\mathrm{u}$ vremenu nastanka i uporabe Imovnika, još su rjeđi. ${ }^{23}$
Jedini zapis u Imovniku koji možemo pouzdano povezati s nekim od sačuvanih predmeta jest onaj o križu »koji se nosi pred nadbiskupom « [69]. Posrijedi je križ koji se danas čuva u Moćniku, načinjen u Dubrovniku, s natpisom u kojem se spominje ime nadbiskupa Rainalda Grazianija i godina 1516. te koji danas služi kao »katedralno ophodno raspelo«. ${ }^{24} \mathrm{Za}$ taj se križ drži da mu je to bila i izvorna namjena te da je posrijedi Grazianijev dar katedrali. ${ }^{25}$ Prva je od tih tvrdnji netočna, a druga samo djelomice točna.

Prije svega, navod u Imovniku - una croze con el baston darzento qual si porta davanti lo arziveschovo - nedvosmisleno upućuje na namjenu tog predmeta. Posrijedi nije ophodni (procesijski), nego tzv. metropolitski križ. ${ }^{26}$ Premda su oblikovanjem identični, ophodni i metropolitski križevi razlikuju se po svrsi: prvi su liturgijski predmeti, a drugi pontifikalne insignije, ${ }^{27}$ nošeni kao znak časti ispred nadbiskupa metropolita kada su izlazili u javnost, i to tako da je strana s Raspetim bila okrenuta prema prelatu. Iz navoda u VI. svesku djela Illyricum sacrum, tiskanom 1800. godine - o »srebrnom križu koji se nosi ispred nadbiskupa kada hoda ulicama grada - može se zaključiti da je raspelo o kojem je ovdje riječ tako korišteno još potkraj 18. stoljeća. ${ }^{28}$ Kao dokaz tome da ga je prvostolnici "ostavio« nadbiskup Graziani u tom se tekstu ističe »Rainaldovo ime urezano [na križu] velikim slovima« ${ }^{29}$

Sve do danas nije, međutim, primijećeno da se - riječima ET PROCV<ratores $>-\mathrm{u}$ tom oštećenom, ali još čitljivu natpisu uz Grazianijevo puno ime, nadbiskupski naslov i godinu 1516., bilježe i prokuratori (dubrovačke katedrale Gospe Velike).$^{30}$ Spomen u natpisu Graziani je, dakle, zavrijedio ne kao jedini, nego kao jedan od aktera naručivanja i darivanja križa.

U zapisu o tom križu u Imovniku [69] Grazianijevo ime, međutim, ne spominje. Zapravo u temeljnom popisu iz 1531. nijedan predmet nije izrijekom povezan s nekom osobom ili

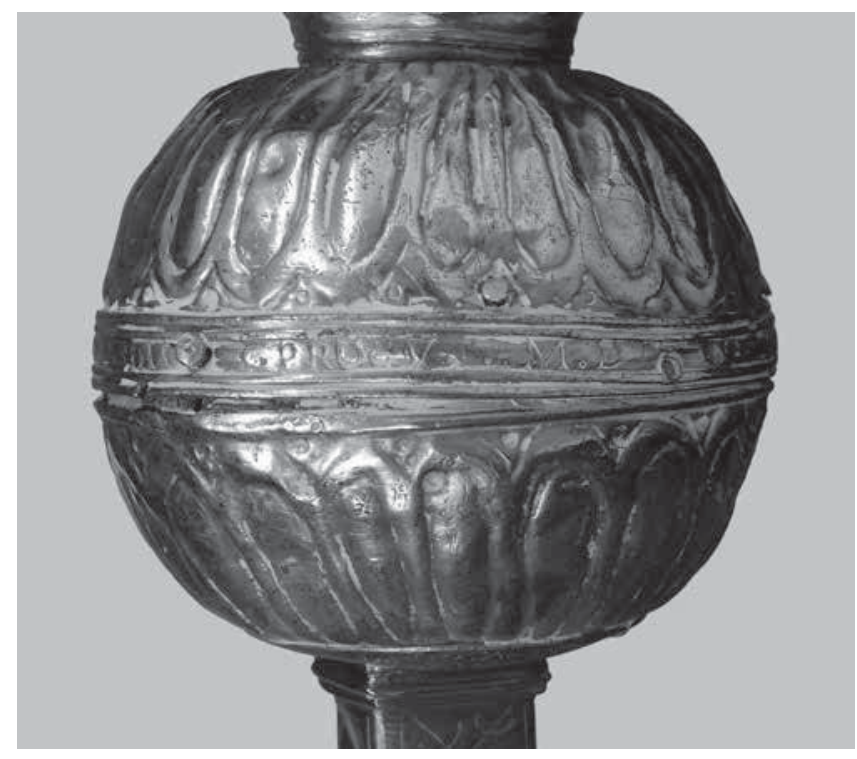

3. Nodus metropolitskog križa, detalj natpisa u kojem se spominju katedralni prokuratori

Node of the metropolitan cross with part of the engraved inscription mentioning the procurators of the cathedral 
rodom, premda, po analogiji s relikvijarima u Moćniku i sa srodnim popisima katedralnih inventara, ${ }^{31}$ ne treba sumnjati da je, osim metropolitskog križa, u dubrovačkoj katedrali bilo i drugih liturgijskih predmeta s natpisima, grbovima ili heraldičkim znakovima koji su svjedočili o njihovim bivšim vlasnicima, naručiteljima ili donatorima.

O tome da je boravak Rainalda Grazianija u Dubrovniku protekao u harmoničnim odnosima sa stanovništvom i vlastima Republike svjedoči i njegov oporučni legat prvostolnoj crkvi $[71] .^{32}$ Grazianijeva nadbiskupska mitra i svilene pontifikalne rukavice, uz koje će se u Dubrovniku vezati trajna uspomena na tog prelata, ${ }^{33}$ zapravo su jedini predmeti koje je on uistinu darovao katedrali. Zahvaljujući zapisu u Imovniku, uz točan datum njihova prispijeća - 22. lipnja 1532. - i podatak da ih je u Dubrovnik osobno donio Grazianijev nećak Marko, sada znamo i da je mitra bila ukrašena likovima sv. Vlaha i sv. Nikole na prednjoj, te sv. Petra i sv. Pavla na stražnjoj strani.

\section{Dubrovački Imovnik i srodni inventarni popisi katedralnih riznica Dalmacije i Hrvatskog primorja}

U neveliku korpusu sačuvanih starijih inventarnih popisa predmeta u katedralnim riznicama Dalmacije i Hrvatskog primorja dubrovački se Imovnik ne može ubrojiti među najstarije. Iz 14. stoljeća potječe tekst splitskog (iz 1342.); ${ }^{34}$ najstariji zadarski popis načinjen je $1427 .,{ }^{35} \mathrm{krčki} 1500 .,{ }^{36} \mathrm{a}$ trogirski 1517. godine. ${ }^{37}$ Desetljeće mlađi od dubrovačkog je korčulanski popis (iz 1541.), ${ }^{38}$ a iz 16. stoljeća potječe i najstariji sačuvani inventar rapske katedrale (iz 1579./1582.). ${ }^{39}$

Premda im svojim izvanjskim obilježjima više ili manje sliči, dubrovački se Imovnik iz 1531. godine od nabrojanih popisa razlikuje ovim svojstvima:

1. Imovnik obuhvaća isključivo liturgijsku opremu, paramente i ruho, tj. ne uključuje relikvijare ni kultne predmete od plemenitih kovina.

2. Imovnik je zaseban dokument. Uz iznimku krčkog iz 1500. (koji je prijepis dijela zapisnika nadbiskupske vizitacije), svi su navedeni slični popisi dijelovi dokumenata koji imaju oblik javnih (notarskih) isprava, najčešće sastavljanih prigodom primopredaja imovine katedralnih riznica.

3. U Imovniku nije zapisano tko ga je sastavio, ni po čijem nalogu.

4. Protivno raširenoj praksi kod sastavljanja srodnih dokumenata, sastavljač Imovnika nigdje se ne poziva na neki stariji popis.

Polazeći od tih zapažanja - usprkos činjenici da je Imovnik, kao što je istaknuto u uvodnom dijelu ovoga rada, 'osamljeni izvor', tj. jedini takav izvor svoje vrste u Dubrovniku - moguće je preliminarno ocrtati društveni, crkveni i politički ambijent te administrativni kontekst njegova nastanka.

$\mathrm{Na}$ svoj je način u tom pogledu znakovita činjenica da su u Imovniku evidentirani i predmeti koji su pripadali tadašnjem dubrovačkom nadbiskupu - bio je to Milanac Filippo Trivulzio (nadbiskup od 1521. do 1543.) - ali se njegovo ime nigdje ne bilježi, a imenom se, štoviše, u temeljnom popisu ne spominje ni ikoji drugi crkveni uglednik. Poznato je da je u vrijeme nastanka Imovnika u Dubrovniku o imovini katedrale već stoljećima preko svojih izabranih dužnosnika skrbila javna vlast. Pojednostavnjeno rečeno, u svijetu komuna katedrale su bile samo 'posjednici' dragocjenosti koje su u njima bile pohranjene, a svaku dvojbu o tome tko im je u Dubrovniku smatran stvarnim vlasnikom otklanja dvjestotinjak godina stariji popis relikvija dubrovačke prvostolnice (iz 1335.), ${ }^{40} \mathrm{u}$ kojemu su zabilježena imena četvorice aktualnih javnih dužnosnika, ali ne i tadašnjeg nadbiskupa (Ilije Sarake)!

Premda u Imovniku iz 1531. neće biti zapisana ni imena svjetovnih dužnosnika, taj je dokument još jedno prvorazredno svjedočanstvo da je u Dubrovniku liturgijska oprema katedrale od relikvijara sa svetim moćima bila odijeljena ne samo prostorno, nego i administrativno. Pokazatelje tome nalazimo još u vremenima iz kojih su sačuvana tek rijetka pisana vrela: od trećeg se desetljeća 13. stoljeća u dubrovačkim dokumentarnim vrelima spominju dvije vrste komunalnih dužnosnika čiji je djelokrug među inim uključivao i nadzor nad dragocjenostima u prvostolnici - rizničari i prokuratori Sv. Marije Velike. ${ }^{41}$ I jedni i drugi bili su svjetovne osobe, birane među najuglednijim pripadnicima društvene elite. Rizničari (thesaurarii, isprva zvani i procuratores thesauri) bili su zaduženi za svete moći, a prokuratori (procuratores operis) za liturgijsku opremu.

Djelovanje katedralnih prokuratora bilo je (kao i djelovanje rizničara) isključivo u nadležnosti tijela svjetovne vlasti, o čemu svjedoče mnoge odredbe u zakonskim zbirkama Komune/Republike. ${ }^{42} \mathrm{U}$ njima, međutim, ne nalazimo odluke kojima bi se prokuratore izrijekom obvezivalo na izradu i/ili vođenje inventara liturgijske opreme prvostolne crkve. Prema uvriježenoj administrativnoj praksi, u Dubrovniku i drugdje, dokumentima poput Imovnika obično je prethodio prijepis odluke koju je o tome donijelo mjerodavno tijelo, bilo da je riječ o redovitim popisima, bilo da se iz nekog razloga (najčešće zbog sumnje u urednost postojeće evidencije ili poštenje odgovornih) naredilo da se načini 'izvanredan' popis. No budući da je savjesno upravljanje imovinom crkvenih ustanova podrazumijevalo i periodično sastavljanje i vođenje evidencija njihovih dobara, vjerujemo da u konkretnom slučaju nije riječ o dokumentu koji je načinjen ad hoc, nego o standardnom, redovitom inventarnom popisu. To ne isključuje mogućnost da je Imovnik sastavljen slijedom izričite naredbe (na što bi mogao upućivati prazan drugi list sveščića gdje je taj akt možda trebao biti zapisan), no u tom bi se slučaju jamačno radilo o nalogu ovlaštenoga crkvenog tijela. Pomisao da bi Imovnik iz 1531. bio nastao voljom svjetovnih vlasti malo je vjerojatna jer pregledavajući zapisnike Vijeća umoljenih i Malog vijeća iz druge polovice 1531. godine nismo pronašli ništa što bi upućivalo na takav zaključak.

Imovnik iz 1531. godine najvjerojatnije je bio jedan u nizu sličnih popisa liturgijske opreme dubrovačke katedrale, a - budući da se njegov sastavljač nigdje ne poziva na neku stariju evidenciju - možda i prvi koji je zamišljen i oblikovan kao zaseban dokument. 


\section{Prilog: Prijepis Imovnika liturgijske opreme, ruha i paramenata prvostolne crkve Gospe Velike (Sv. Marije Velike) u Dubrovniku iz 1531. godine}

Napomena uz transkripciju

Brojevi u uglastim zagradama u lijevom stupcu (oznake pozicija) ne pripadaju izvorniku, a riječi ili znakovi dodani u tekst prijepisa radi lakšeg razumijevanja omeđeni su šiljatim zagradama. Nadalje, u tekstu su po načelima logičke interpunkcije mjestimice umetnuti i zarezi. Dijelovi teksta dopisani u temeljnom popisu omeđeni su znakovima $L$ i 」, a naknadni su upisi u rubrikama odvojeni proredom.

$\dagger$ Laus Deo. 1531, adi 15 di dezenbrio

Inventario dela giexia di S. Maria Mazor de tute le argentarie, aparati deli sazerdoti, insenarii, libri, tapezarie et altre robe, chome qui di sotto et in avanti apare. E prima:

Argentarie

[1] Uno chruzifixo con dua figure atorno et quatro evangielisti, tuto darzento, posto sopra el corro

[2] Chandilarii zinque darzento posti sotto el deto chruzifixo

[3] Votti varii e diversi darzento e de varie e diverse forme hoferti alo altar de la Madona verso le porte, fra li quali e uno hochio dorro, quali sono atachati a uno ferro et zerto drapo, pesano lire hottu, onze ssei vel zircha, chonputando el ferro e lo drapo

L. 8 , on. 6

[4] Uno vaso per sachramento di arzento, pesa lire due, onze dua $\quad$ L. 2, on. 2

[5] Uno inzensiero di arzento, pesa lire quatro, onze hottu, val $\quad$ L. 4, on. 8

$\begin{array}{ll}\text { [6] Ittem un altro inzensiero di arzento, pesa lire tre, onze undexi } & \text { L. 3, on. } 11\end{array}$

[7] Uno sichio di arzento di aqua benedeta con suo aspergile di arzento, pesa lire tre, onze dua, val

L. 3 , on. 2

[8] Una naveta de inzensio darzento, pesa lire una, onze una

L. 1 , on. 1

[9] Ittem un altra naveta darzento, pesa lire una, onze tre

L. 1 , on. 3

[10] Uno pax techum darzento con la Pietta, pesa lira una, onze ssei

L. 1 , on. 6

[11] Ittem un altro pax techum di arzento con la Pietta, pesa lire una, onze dexe, val

L. 1 , on. 10

[12] Bochete ssei darzento con le figie di rame, pesa lire dua, onze una

L. 2 , on. 1

[13] Anpulete dua darzento, pesa lire una, onze dexe, val

L. 1 , on. 10

[14] Una croze darzento de numero 1, pesa lire una, onze quatro e mezo, val

L. 1 , on. $4^{1 / 2}$

[15] Una croze darzento de numero 2, pesa lire una, onze zinque, val

L. 1 , on. 5

[16] Ittem una croze darzento de numero 3, pesa lire una, onze sette e mezo, val

L. 1 , on. $7 \frac{1}{2}$

[17] Ittem una croze darzento de numero 4, pesa lire una, onze nove, val

L. 1 , on. 9

[18] Ittem una croze darzento de numero 5, pesa lire una, onze nove, val

L. 1 , on. 9

[19] Uno calize darzento grande de numero 1, pesa lire quatro, onze nove e mezo, val

[20] Una croze duplichata, di dentro legnio et la coperta darzento, conputando el legnio pesa lire una, onze undexi e mezo

[21] Uno calize darzento de numero 2, pesa onze undexe e mezo

L. - , on. $11^{1 / 2}$

[22] Ittem uno calize darzento de numero 3, pesa lire una, onze una e mezo, val

L. 1 , on. $1 \frac{1 / 2}{2}$ Ittem uno calize darzento de numero 4, pesa lire una, onze dua e mezo, val 
segue argentarie

[24] Uno calize darzento de numero 5, pesa lire una, onze ssei, sagi dua

L. 1 , on. 6 , s. 2

[25] Ittem uno calize di arzento de numero 6, pesa onze nove, val

L. - , on. 9

[26] Charafe tre grande darzento quale non sono pesate per eser dentro chrisma, hoglio santo et hoglio de infirmo

[27] Pomi tre con bottoni de chapuzi de pluviali, sono darzento lavorati al filo, pesa lire una, onze ssei, conputando la seda et orro filato, val

L. 1 , on. 6

[28] Uno pastoral darzento, pesa lire dexe, onze quatro, sagi tre conputando el baston di dentro, val

L. 10 , on. 4 , s. 3

[29] Pattene dexidottu deli calizi darzento, fra le quale sono dua pattene de doi calizi grande, pesano tute lire hottu, onze dua, val

L. 8 , on. 2

[30] Uno calize darzento de numero 7, pesa onze nove, sagi tre

L. - , on. 9, s. 3

[31] Ittem uno calize darzento de numero 8, pesa onze undexe

L. -, on. 11

[32] Ittem uno calize darzento de numero 9, pesa lire una, onze tre, sagi tre

L. 1 , on. 3 , s. 3

Ittem uno calize darzento de numero $\mathrm{X}$, pesa lire dua, onze sete, sagi tre, val

L. 2 , on. 7 , s. 3

L. -, on. 9, s. 2

L. - , on. 8 , s. 3

Ittem uno calize darzento de numero 12, pesa onze ottu, sagi tre

Ittem uno calize darzento de numero 13, pesa lire una, sagi zinque

L. 1, on. -, s. 5

Ittem uno calize darzento de numero 14, pesa lire una, sagi zinque

Ittem uno calize darzento de numero 15, pesa lire nule, onze dexe, sagi tre, val

[39] Ittem uno calize darzento de numero 16, pesa onze ottu, val

L. 1 , on. - , s. 5

L. - , on. 10 , s. 3

L. - , on. 8

[40] Ittem uno calize darzento de numero 17, pesa onze nove, sagi tre

[41] Ittem uno calize darzento de numero 18, pesa onze sette, sagi quatro, val

L. - , on. 9, s. 3

L. - , on. 7 , s. 4

[42] Ittem uno calize darzento de numero 19, pesa lire una, onze dua

L. 1 , on. 2

[43] Ittem uno calize darzento con la sua pattena de numero 20, qual non e pesato per esser da mon signor arziveschovo

[44] Choverte darzento de uno evangielistar posto avanti, in lo aventario deli libri, pesano lire dua, onze dua, sagi quatro

L. 2, on. 2. s. 4

[45] Uno bochal grande darzento lavorato al ponzon, pesa lire quatro, onze nove, val

L. 4 , on. 9

sume L. 42 , on. 6 , sagi 1

segue argentarie

[46] Uno bazil darzento lavorato al ponzon, pesa lire quatro, onze una, val

[47] Una anpuleta con uno paro, che sono anpulete due, per altar grande, pesano lire una, onze dexe, val

[48] Una croze darzento de numero 6 biancha, con la figura di S. Pietro de una banda e del altra el cruzifiso, pesa lire quatro, onze ottu, val

[49] Chuchiare dua darzento per le navette de inzensio, pesano onze una, sagi dua e mezo, val

L. 4 , on. 1 , s. -

L. 1 , on. 10 , s. -

L. 4 , on. 8 , s. -

L. - , on. 1, s. $2^{1 / 2}$

[50] Una croze darzento, de numero 7, de fora e dentro legnio, con el cruzifiso de una banda e del altra la Madona, pesa lire tre, onze ottu, computando lo legno et lo rame, val

L. 3 , on. 8 , s. -

[51] Una croze di rame indorata de numero 8, qual non e pesata

[52] Una croze di ferro de numero 9 con letere greche qual non e pesata

[53] Una croze grande con la corona, qual non e pesata ma al iudizio del maistro dise che era darzento zircha lire ssei, val 
[54] Uno inzensier darzento, pesa lire quatro, onze tre

L. 4 , on. 3 , s. -

[55] Uno busulo darzento per Corpus Cristi con la pedata di rame, de sopra una croze, quadrat, con tondeti xmaldati, pesa lire una, onze ottu, sagi tre, val

L. 1 , on. 8. s. 3

[56] Ittem uno busulo darzento tondo con la pedata di rame, pesa lire una, onze zinque, sagi tre, val

L. 1 , on. 5 , s. 3

[57] Ittem uno busulo darzento, lavorato ali pometi, con campanelo et con la croce di sopra, pesa lire dua, onze ssei, val

L. 2 , on. 6 , s. -

[58] Ittem uno busulo darzento lavorato ale sunde, pesa lire dua, onze ssei, val

L. 2 , on. 6 , s. -

[59] Una croze di ferro qual si uxa portar drio li morti, la qual non e pesata

[60] Uno tabernachulo per Corpus Cristi darzento con lo gristaldo, pesa lire zinque, val

L. 5, on. - , s. -

[61] Agii ottu darzento al croze, pesano onze tre, sagi dua

L. -, on. 3 , s. 2

sume L. 38, onze -, sagi $4 \frac{1}{2}$

[62] Una croze pichula di arzento con la catena darzento per mon signor, pesa onze tre, sagi tre, val

[63] Uno anelo epischopale darzento, pesa onze dua, sagi zinque, val

[64] Una corona darzento con fiori dexi e con le zoie, pesa onze ottu, sagi tre, val

[65] Ittem una corona darzento con fiori dexi e con zoie, pesa onze ottu, sagi quatro, val

[66] Ornamento de dua corone di perle con li tondini darzento, pesa onze zinque, sagi tre, val

[67] Una forfeta darzento, pesa onze una, val

L. - , on. 3 , s. 3

L. - , on. 2 , s. 5

L. - , on. 8 , s. 3

L. - , on. 8 , s. 4

L. - , on. 5, s. 3

L. -, on. 1, s. -

[68] Choverte darzento de uno misal novo, posto avanti in lo aventario deli libri, pesano lire ottu, onze zinque, val

L. 8 , on. 5 , s. -

[69] Una croze con el baston darzento qual si porta davanti lo arziveschovo, non e pesata

[70] Una dmitra di perle di mon signor arziveschovo

sume L. 10, on. 11

$\uparrow 1532$, die XXII iunii

[71] Una dmitra doro cum figure davanti di S. Biaxio e S. Nicolo e da drieto S. Piero e S. Paulo cum pendenti da drieto pendini di argento numero VIII, la qual la bona memoria di reverendissimo mon signor di Raguxi Rainaldo Gratiano di Cotignola per mano di suo nepote misser Marcho doctore decretorum a offerto alla chiexia di Santa Maria cum li guanti di seta baratini

[72] Uno tabernachulo de argento indorato per Corpus Domini, pexo libri tre, onze nove, comprato da Andrea Matchovich per ducati 32, val

L. 3 , on. 9

[73] Uno calize presento ser Francesco Marin de Goce, senza patena

1542

[74] Uno calize de oro con la patena, pesa lire cinque, onze quatro, sagi quatro, lasato per ser Giovani Pal. de Gondola

L. 5 , on. 4 , s. 4

MDXLIIII seguitano le argentarie

[75] Una corona de oro qual fo posita ala figura dela Nostra Dona dele porte, pesa con le gioie lire una, onze tre, sagi dodexi, lo amontar de la qual, cioe le gioe, e di oro in parte, fo lasato da dona Maria olim ser Marino Sil. de Zamagno 
MDLX

[76] Uno turibillo senza naveta, pesa lire

[77] Candilieri dargento numero dexi portati da Roma, pesano

L. $<->$

[78] Catene doro ala Madona dele porte numero tre, pesano

L. $<->$

[79] Un cholarino doro con verozella con perle quatro, pesa

L. - , on. 2, [s.] 1

[80] Una chatenella sutil doro de valuta scudi tre in circha

L. -, on. 1, [s.] 4

L. $<->$

[81] 1575, addi 19 agosto, dua candelieri di argento portati da Roma per ser Gio. Marino di Gondola, pesorno

[82] Itte (!) piu voti di argento pesorno lire tre di bon peso et sono di varie et diverse forme

[83] Itte una cadena onzi tre che pesorno <...>

$\dagger 1560$, adi III de ottobbre

(non sequitur)

\section{$\dagger$ Aparati deli sazerdoti}

[84] Una capela biancha di pano dorro, zioe uno pluviale, planeta, streta, dalmaticha et apreso camixi tre, stole una, manipuli tre, amichti tre indorati et rechamati con horo et perle et zenture tre rose di seta con li cani doro, le qual zenture serveno ali altri aparati. In tuto numero dexe dottu, val

[85] Ittem un altra capela rosa di pano dorro, zioe uno pluviale, planeta, streta, dalmaticha et apreso camixi tre, stolle dua, manipuli tre, in tuto numero dodexe, val

[86] Ittem terza capela di veluto verde, zioe planeta, streta, dalmaticha et apreso camixi tre, stole dua e manipuli tre, val

[87] Ittem quarta capela di damascho biancho, zioe uno pluviale, planeta, streta, dalmaticha et apreso stole dua, manipuli tre et amichti tre. LItem camixi tre novi, val」

[88] Ittem quinta capela di veluto negro, zioe uno pluviale, planeta, streta, dalmaticha et apreso camixi tre, stole dua, manipuli tre et amichti tre, val Ittem sechsta capela di zendato roso, zioe planeta, streta, dalmaticha, val

(vacuum)

\section{$\dagger$ Planete}


[96] Ittem terza planeta di damasscho biancho con la festa romana di seta verde lavorata aposta dorro con la croze de drieto rechamato, val

[97] Ittem quarta planeta di damasscho biancho con li fiori dorro et con la croze de drieto rechamato, val

[98] Ittem quinta planeta di damasscho biancho con li fiori dorro, e de seta verde e rosa e con la croze da drieto rechamato, val

[99] Ittem sechsta planeta di damasscho negro con la croze davanti e da drieto lavorata dorro de Cholognia e davanti con la seta

Ittem septima planeta di damasscho roso con la croze da drieto lavorata con orro di Colognia, val Ittem hochtava planeta di damasscho zelestre con la croze de drieto lavorata con orro di Colognia, val Ittem nonna planeta di damasscho biancho con la croze da drieto rechamata, val $\mathrm{n}^{\mathrm{o}} 1$ Ittem dezima planeta di raso paunazo con la croze <avanti> e da drieto rechamati dorro, val Ittem undezima planeta di damasscho biancho con la croze da drieto rilevata, val Ittem duodezima planeta di veluto negro con la croze da drieto intorno frixo dorro rilevato, val Ittem tredezima planeta di raso negro con la croze davanti e da drieto di orro di Colognia, val $\mathrm{I}<\mathrm{ttem}>$ quartadezima planeta di panno dorro con la croze da drieto rilevata, val

(vacuum)

\section{$\dagger$ Pluviali}

[110] Uno pluviale di pano dorro con li frixi de rechamo, intorno fodrato di tafta rosa, val

[112] Ittem terzo pluviale di panno dorro con li fiori zelestri et con li frixi dorro rechamati, fodrato di tela rosa, val Ittem quarto pluviale di panno dorro con li fiori rosi con li frixi dorro rechamati, fodrato di tela rosa, val

\section{2}

[116] Pluvialli zinque, zioe uno di damasscho biancho con fior dorro con lli frixi et chapuzo a rechamo, fodrato di tella rosa, val Ittem quarto pluvial di velluto paunazo con frixi et chapuzo a rechamo, fodrato di tella verde 
(vacuum)

\section{$\dagger$ Pallii}

Uno pallio di veluto zelestre schuro rechamado con le figure e con la corona, val Ittem un altro palio di damasscho biancho con la anunziazion e con la corona, val

[130] Ittem nono palio di chamucha di seta rosa e biancha con la croze di frixo dorro et con la corona, val

[132] Ittem undezimo palio di veluto zelestre con la croze di tondi vintiquatro darzento minor et con la corona di tondi trenta sete darzento mazor, in tuto tondi ssessanta uno, val

[135] Ittem palii tre di veluto verde, videlicet uno con la Nostra Dona, laltro con croze di horro churdola et terzo con la croze di zendado roso, val

[136] Ittem palii sete di tela zelestre schura con le croze di zendato roso, val

[137] Ittem uno palio di veluto zelestre con fiori dorro, fodrato di zendato roso, dela tenda de Corpus Cristi, val

(vacuum)

\section{$\dagger$ Tapeti e razi}

[139] Tapeti tre grandi, uno novo e dua uxati, soliti poner uno a la bancha apreso la sedia de misser lo retor e laltro a la bancha avanti lo altar de Santa Anna e lo terzo al pulpito del predichator, val 
[146] Uno razo figurato frusto, val $\dagger 1538$

[147] Tapeti sette conprati novamente, val 1545

[148] Ittem uno tapeto qual dono la sinoria 1559

[149] Ittem tapeti dua novamente conprati 1562

[150] Ittem tapeti dua novamente conprati 1564

[151] Item uno tapeto grande

(vacuum)

(f. 10 deest)

\section{Bilješke}

1

Dokument je zasad bez signature, a s nekoliko je drugih arhivalija pohranjen $\mathrm{u}$ Arhivu biskupije dubrovačke u kutiji s naslovom Ostavština Antuna Vučetića. Nažalost, nisu poznati prethodni vlasnici, kao ni način na koji je Antun Vučetić došao u posjed Imovnika.

2

Povjesničar, pedagog i publicist Antun (Antonije) Vučetić (Dubrovnik, 18. XII. 1845.-16. V. 1931.) bavio se širokim spektrom tema, a danas su možda najpoznatiji njegovi tekstovi iz dubrovačke povijesti 17. stoljeća, posebice o razdoblju uoči i nakon Velike trešnje, kao i knjiga o štovanju svetoga Vlaha u Dubrovniku. Važnost njegovom znanstvenom radu daje činjenica da se bavio istraživanjem dotad uglavnom manje poznatih ili neobjavljenih arhivskih izvora. Značajan je i njegov doprinos u prepisivanju i objavljivanju dubrovačkih arhivskih dokumenata, što je na molbu Franje Račkoga radio za edicije JAZU. Objavio je i čitav niz manjih članaka o pojedinim događajima i osobama iz dubrovačke prošlosti, kao i nekoliko rasprava iz pedagogije. Nakon što je kao dugogodišnji gimnazijski profesor zbog političkih stavova prijevremeno umirovljen preuzeo je uređivanje časopisa $\mathrm{Srd}$ (do 1908.), a nakon Prvoga svjetskoga rata imenovan je prvim direktorom samostalnoga Državnoga arhiva u Dubrovniku (1921.-1924.) i ustrojio je njegov rad. Vučetićevom raznorodnom opusu dosad nažalost nije bila posvećena cjelovita studija, sve do recentne bio-bibliografije iz pera Irene Arsić pod naslovom Antonije Vučetić (1845-1931) istoričar Dubrovnika, objavljene u nakladi Filozofskoga fakulteta u Nišu 2012. godine. Kao jedina nasljednica Antuna Vučetića gospođa Mira Puljizević iz Novoga Sada odredbom je svoje posljednje volje 2016. godine donirala $\mathrm{n}^{\mathrm{o}} 1$

$\mathrm{n}^{\mathrm{o}} 7$

$\mathrm{n}^{\mathrm{o}} 1$

$\mathrm{n}^{\mathrm{o}} 2$

$n^{\circ} 2$

$\mathrm{n}^{\mathrm{o}} 1$

(f. $9 v)$

vrijednu Vučetićevu rukopisnu ostavštinu i knjižnicu Državnome arhivu u Dubrovniku, a pojedine arhivalije pripale su Arhivu biskupije dubrovačke i Dubrovačkim muzejima.

\section{3}

Archivio segreto Vaticano, S. Congregatio Concilii, 1573 Ragusina Visitatio apostolica. Pohod prvostolnici je na ff. $8 \mathrm{r}-37 \mathrm{v}$, a izvatke važne za poznavanje arhitekture, liturgijske opreme i relikvijara objavio je i interpretirao C. Fisković, Umjetnine stare dubrovačke katedrale, u: Bulletin Razreda za likovne umjetnosti JAZU, 14 (1965.), 1-3: 62-75.

4

Na susretljivosti i kolegijalnoj pomoći u pripremi ovog rada zahvaljujemo povjesničarima umjetnosti Silviji Banić, Danijelu Cikoviću i Damiru Tuliću te povjesničaru Antunu Konculu, arhivistu iz Arhiva Biskupije dubrovačke.

5

Točan im broj nije moguće utvrditi jer su zavjetni darovi evidentirani zbirno.

6

U izvorniku: lire, onze i sagii. Dubrovačka »tanka libra « ili librica (libra ad pondus subtile) iznosila je približno $328 \mathrm{~g}$, a dijelila se na 12 unci $(27,33 \mathrm{~g})$ i 72 heksagije $(4,55 \mathrm{~g})$.

7

Premda se čitanjem zapisa na prvi pogled stječe dojam da je riječ o srebrnoj kruni, čini se da je i križ bio načinjen od srebra; na to prije svega upućuje težina, ali i slično stilizirani zapisi o krunama za ikonu Bogorodice s djetetom [64; 65]. 
Posrijedi su možda kuglice na iglama kojima su ukrašavani krakovi raspela. Premda se čini da im to nije bila izvorna svrha, oko njih su se običavale omatati vrpce, usp. primjerice fotografije dvaju korčulanskih raspela - bratovštine Svih Svetih, djela Ivana Progonovića, i raspela iz Žrnova - u tekstovima CVITO FISKOVIĆ, Dubrovački zlatari od XIII do XVII stoljeća, u: Starohrvatska prosvjeta, III. s., 1 (1949.), tabla III, i ALENA FAZINIĆ, Dva gotička srebrna ophodna raspela s otoka Korčule, u: Peristil, 29 (1986.), 37.

9

Možda je posrijedi flabello (lat. flabellum), svojevrsna lepeza kojom su tijekom liturgijskih čina tjerani insekti, usp. Dizionari terminologici - Suppellettile ecclesiastica I, (prir.) Benedetta Montevecchi - Sandra Vasco Rocca, Firenze, 1989., 144-145.

\section{0}

Vrste tkanine: pano dorro (zlatna tkanina), veluto (baršun), damascho (damast), zendato (cendal), brochato (brokat) i tela (platno); boje: biancha (bijela), rosa (crvena), verde (zelena); negro (crna) i paunazo (ljubičasta).

11

Od lat. stricta tunica, potom i samo stricta; taj se predmet $\mathrm{u}$ talijanski pisanim izvorima katkad naziva i tunicella, usp. JOSEPH BRAUN, Die Liturgische Gewandung im Occident und Orient nach Ursprung und Entwicklung, Verwendung und Symbolik, Freiburg im Breisgau, 1907., 288.

12

Uz navedene vrste tkanina (zlatna tkanina, damast, baršun, brokat), u popisu misnica javlja se i raso (raša).

13

Kölnsko zlato (oro di Colognia) oznaka je za karakterističnu vrstu zlatnih niti nazvanih po mjestu proizvodnje, odakle su se izvozile u druga središta tekstilne djelatnosti, v. GIORGIO SANGIORGI, Contributi allo studio dell' arte tessile, Milano, 1920., 24.

\section{4}

Uz navedene vrste tkanina (baršun, damast, platno) u popisu antependija javljaju se i horpelo (tkanina od lažnog zlata), seta (svila) i chamucha (lampas), a od boja zelestre (nebeskoplava), zelestre schuro (tamnoplava, ili potamnjela plava) i giala (žuta).

15

Prema zapisniku Sormanijeve vizitacije (bilj. 3), ff. 28r-29r, godine 1573. dio liturgijske opreme prvostolnice čuvan je u kući katedralnih prokuratora, u prostoriji također zvanoj sakristija.

\section{6}

Taj opisni izraz zacijelo se odnosi na karakterističan renesansni motiv ukrašavanja zlatarskih izrađevina polukuglastog oblika konvergentnim ispupčenim radijalno raspoređenim i oblo završenim poljima, nalik kanelirama; usp. ukras nodusa na sl. $3 \mathrm{u}$ ovom tekstu. Francuski je naziv - godron - preuzet i u engleskoj i njemačkoj stručnoj terminologiji.

17

Većina je križeva zacijelo bila izrađena lijevanjem u kalupu, iskucavanjem u srebrnom limu prema matrici ili kombinacijom tih dviju tehnika.

18

$\mathrm{O}$ aleksandrijskim sagovima $\mathrm{u}$ inventarima opreme dubrovačkih stambenih interijera vidjeti: NEVENKA BEZIĆ-BOŽANIĆ, Dubrovačka kuća prvih godina 17. stoljeća, u: Građa i prilozi za povijest Dalmacije, 12 (1996.), 376.

19

Za osnovne biografske podatke o nadbiskupu Grazianiju (Cotignola kraj Ravenne, oko 1465. - Bologna, 1529.) v. STJEPAN
KRASIĆ, Graziani, Rainaldo, u: Leksikon Marina Držića, Zagreb, 2009., 279-280.

20

IVO LENTIĆ, Zlatarstvo, u: Zlatno doba Dubrovnika XV. i XVI. stoljeće, katalog izložbe, Zagreb, 1987., 230.

21

Dokument o tome objavljen je u monografiji Katedrala Gospe Velike u Dubrovniku, (ur.) Katarina Horvat-Levaj, Dubrovnik - Zagreb, 2014., 550, s. d. 22. II. 1711.: de comittendo Dominis Thesaurariis, et Procuratoribus Sanctae Mariae Maioris uti praevia dispensatione Ordinarii faciant liquefacere totum id fracti Argenti, quod reperitur in Reliquiarum deposito, faciendo seiungere Aurum ab Argento, et quod reducant totum in pecunia numerata quam debeant reponere ad fructum in hac Zecca ad dispositionem Excellentissimi Senatus pro beneficio supradictae Ecclesiae.

22

JELENA IVOŠ, Liturgijsko ruho, u: Katedrala Gospe Velike u Dubrovniku, (ur.) Katarina Horvat-Levaj, Dubrovnik - Zagreb, 2014., 339.

23

VINICIJE B. LUPIS, Liturgijski predmeti i zavjetni darovi, u: Katedrala Gospe Velike u Dubrovniku, (ur.) Katarina Horvat-Levaj, Dubrovnik - Zagreb, 2014., 319.

24

VINICIJE B. LUPIS, Ophodno raspelo dubrovačkog nadbiskupa Reinalda Gratiana iz 1516. godine, u: Radovi Instituta za povijest umjetnosti, 27 (2003.), 81-84; VINICIJE B. LUPIS (bilj. 23), 320-322, 509.

25

VINICIJE B. LUPIS (bilj. 24), 81-84; STJEPAN KRASIĆ (bilj. 19), 279; VINICIJE B. LUPIS (bilj. 23), 320-322, 509.

26

U Imovniku se zacijelo stoga, za razliku od dvaju ophodnih raspela $[48 ; 50]$, ne bilježi ni podatak o liku (Bogorodici) na stranici nasuprot Raspetomu.

27

Metropolitski se križ spominje u Rimskom pontifikalu, među odredbama o paliju: »Izabrani [metropolit] ne smije dati pred sobom nositi križ prije no što mu bude podijeljen palij (Neque ante habitum Pallium potest Electus ante se crucem deferre, sed tantum postea.). Nav. prema Pontificale Romanum Clementis VIII Pontificis Maximi iussu restitutum atque editum, Romae, 1595., 121. 28 DANIEL FARLATI, Illyricum sacrum, VI. Ecclesia Ragusina cum suffraganeis, Venetiis, 1800., 219: Basilicae Cathedrali Ragusinae [Archiepiscopus Raynaldus] reliquit non levia sui erga illam memoris beneficique animi monumenta, videlicet Crucem argenteam, quae Archiepiscopo per vias urbis incedenti praeferri solet (...).

29

N. mj.: (...) et donum ejus esse declarat nomen Raynaldi litteris majusculis insculptum.

30

Natpis na obodu nodusa: RAYNALDVS GRATIANVS DE COTIGNO $\cdot$ ARCHIE $\cdot$ RAG $\cdot \mathrm{ET} \cdot \mathrm{PROCV} \cdot \mathrm{MDXVI}$.

Nodus je prigodom popravka 1775. godine okrenut naopako tako da je otvor koji je izvorno služio za umetanje štapa zatvoren okruglom pločicom na koju je potom montiran križ. Na pločici je ugraviran natpis u kojem imenima autora, dubrovačkih zlatara Rafa i Stijepa Radelje, te godini zahvata prethodi prilično vjerno 
ponovljen tekst starijeg natpisa: RAYNAL. GRATIANVS. A. COTINIOLA. ORD: MIN: ARCHIEPI. RAGVSINVS. ET. PROCVR. MDXVI. STEPH: ET RAPH: RADEGLIA. RESTAV. 1775.

31

Usp. primjerice imena biskupa, plemićkih obitelji i gradskih knezova u popisu predmeta u riznici trogirske katedrale iz 1517. - NEVENKA BEZIĆ-BOŽANIĆ, Prilog poznavanju riznice trogirske katedrale, u: Prilozi povijesti umjetnosti u Dalmaciji, 21 (1980.), 405-407.

\section{2}

Grazianijevu mitru i rukavice, ali ne i križ (!), spominje NIKOLA RAGNINA, Annali di Ragusa del magnifico ms. Nicolò di Ragnina, u: Annales Ragusini anonymi item Nicolai de Ragnina, (prir.) N. Nodilo, [Monumenta spectantia historiam Slavorum meridionalium, 14; Scriptores, 1], Zagrabiae, 1883., 276.

\section{3}

U rukopisnom djelu Narrazioni o vero storia degli Arcivescovi di Raugia, napisanu 1587-1588, dobrim dijelom zasnovanu na Ragnininim Analima, Serafino Razzi zabilježio je da mitra i rukavice vrijede 50 dukata, te da su u njegovo doba još uvijek čuvani na Grazianijevu uspomenu, vidjeti: STJEPAN KRASIĆ - SERAFINO RAZZI, Povijest dubrovačke metropolije i dubrovačkih nadbiskupa (X.-XVI. stoljeća), Dubrovnik - Split, 1999., 132.

34

DANIEL FARLATI, Illyricum sacrum, III. Ecclesia Spalatensis olim Salonitana, Venetiis, 1765., 317-318; Diplomatički zbornik Kraljevine Hrvatske, Dalmacije i Slavonije, sv. 11: Listine godina 1342-1350, (prir.) Tadija Smičiklas, Zagreb, 1913., 7-11.

35

IVO PETRICIOLI, Najstariji inventar riznice zadarske katedrale, u: Prilozi povijesti umjetnosti u Dalmaciji, 26 (1986.-1987.), 157-166.

36

MATO POLONIJO, Najstariji sačuvani inventar stolne crkve u Krku, u: Croatia sacra, 13-14 (1937.), 108-118.
37

NEVENKA BEZIĆ-BOŽANIĆ (bilj. 31), 403-410.

38

IVO MATIJACA - ALENA FAZINIĆ, Liturgijsko srebro iz Opatske riznice u Korčuli, u: Peristil, 27-28 (1984.-1985.), 221-232.

39

MATO POLONIJO, Najstariji sačuvani inventari bivše stolne crkve u Rabu, u: Croatia sacra, 15-16 (1938.), 59-72.

40

Državni arhiv u Dubrovniku, XIV. Chiese e Monasteri, 1. Reliquie sanctorum corporum reperte in Ecclesia Cathedrali Sancte Mariae.

41

Temeljne rasprave o rizničarima i prokuratorima ostaju KOSTO VOJNOVIĆ, Crkva i država u dubrovačkoj republici, u: Rad Jugoslavenske akademije znanosti i umjetnosti, 119 (1894.), 32-142, te KOSTO VOJNOVIĆ, Državni rizničari republike dubrovačke, u: Rad Jugoslavenske akademije znanosti i umjetnosti, 127 (1896.), 1-101. Podrobnije o prokuratorima v. ZDENKA JANEKOVIĆ RÖMER, Okvir slobode: dubrovačka vlastela između srednjovjekovlja i humanizma, Zagreb - Dubrovnik, 1999., 118-125, 212-213, a o rizničarima NELLA LONZA, 'Za spas duša, na dobrobit države’: Dubrovački rizničari i vremenita dobra za vječnu nabožnu svrhu (13-15. stoljeće), u: Danko Zelić (prir.), 'Liber affictuum thesaurarie (1428-1547)': Knjiga vječnih najmova oporučnim legatima namijenjenih nabožnim djelima, Zagreb Dubrovnik, 2012., 9-24

42

Statut grada Dubrovnika sastavljen godine 1272, (prir.) Zdenko Šundrica, Ivo Veselić i Ante Šoljić, Dubrovnik, 2002.; Liber omnium reformationum civitatis Ragusii / Knjiga svih reformacija grada Dubrovnika, (prir.) Aleksandar Solovjev, Beograd, 1936.; Liber viridis, (prir.) Branislav M. Nedeljković, Beograd, 1984.; Liber croceus, (prir.) Branislav M. Nedeljković, Beograd, 1997. 
Summary

\author{
Danko Zelić - Ivan Viđen \\ Inventario dela giexia di S. Maria Mazor, de tute le argentarie, aparati deli sazerdoti, \\ insenarii, libri, tapezarie et altre robe (1531) - the Oldest Extant Inventory of Liturgical \\ Objects, Vestments and Textiles of Dubrovnik Cathedral
}

\begin{abstract}
A hitherto unknown manuscript booklet containing inventory of liturgical items, vestments, paraments, and textiles of Dubrovnik cathedral made in 1531 is edited and published here for the first time. Recently donated to the Archives of Dubrovnik bishopric, it is not just the oldest surviving source of this particular kind pertaining to the Dubrovnik cathedral, but indeed the only complete register of its liturgical utensils and textiles from the time before 1667, i.e. the great earthquake in which the medieval building was devastated.

Written in vernacular Italian inside the quire consisting of eleven parchment leafs, the inventory has six sections (rubrics). The first, entitled Silverware (Argentarie; ff. $1 \mathrm{r}-2 \mathrm{v}$ ), records the most precious objects - liturgical vessels and utensils, liturgical and processional crosses, pontifical insignia etc. The textile items are divided into Mass vestment sets (Aparati deli sazerdoti; f. 4r), chasubles (Planete; f. 6r), copes (Pluviali; f. 7r), pallia (Pallii; f. 8r), and carpets and mats (Tapeti e razi; f. 9r). The inventory had also originally included the list of liturgical books of the cathedral, in all probability written on the missing last leaf of the booklet.
\end{abstract}

All records in the inventory specify the names/types of the objects, material and numerical values - the weight of the objects (for the metalware) as well as the number of separate parts for the sets of vestments. In many instances the descriptions also include the details on the techniques and ornamentation.

Judging by its overall appearance as well as its original foliation, the inventory was not part of a larger whole but a document of its own, created with the purpose to serve as the principal register of liturgical utensils, paraments, and vestments of the cathedral. Accordingly, from 1532 onwards in the blank spaces that were intentionally left between the rubrics (ff. $4 \mathrm{v}-5 \mathrm{v}, 6 \mathrm{v}, 7 \mathrm{v}, 8 \mathrm{v}, 9 \mathrm{v}$ ) new items have been recorded until the year of 1575 . Thus, the inventory remained in use for almost half of the century. The main list, made at the end of 1531, comprises more than 280 items and further 45 objects were recorded subsequently, until 1575.
With regard to its contents, it should be stressed that the inventory does not include the most precious objects held in the cathedral - the reliquaries. In Dubrovnik the holy relics and their containers were periodically inventoried in separate documents (the earliest extant inventory of the relics in the cathedral was composed in 1335). In fact, the treasury of Dubrovnik cathedral consisted of two distinct groups of objects: the reliquaries with holy relics on the one hand, and liturgical utensils, vestments, and paraments on the other hand. From the early thirteenth century at least they had been kept separately, placed under the supervision of two distinct types of secular officials. The treasurers (thesaurarii) were responsible for the reliquaries, housed in the reliquary chamber, whereas the procurators (procuratores) were entrusted with the care for liturgical furnishings and objects in the sacristy.

The precise circumstances and/or the occasion for the making of the inventory are, however, not stated and the name(s) of either ecclesiastical or secular dignitary or body who ordered that the inventory be made are missing. In spite of the fact that several objects have been registered as belonging to mon signor or mon signore arziveschovo, i.e. the archbishop Filippo Trivulzio of Milan, his name does not appear in the booklet either.

The only extant object recorded in the inventory is the cross made in Dubrovnik in 1516 with an inscription mentioning its commissioners - the archbishop Rainaldo Graziani and the procurators of the cathedral. Its description in the inventory - una croze ... qual si porta davanti lo arziveschovo - makes obvious that it was not intended to serve as a processional cross (as it was believed and as it is used nowadays) but as a metropolitan cross, a sign of archiepiscopal dignity solemnly carried in front of the prelate during his appearances in public.

Key words: Dubrovnik, Cathedral of the Assumption of the Virgin, Sixteenth century, treasure, inventory 


\section{Izvori ilustracija i autori fotografija / Sources of illustrations and photo Credits}

\begin{abstract}
Laura Chinellato
Le lastre longobarde del »pulpito di Maviorano« di Gussago (Brescia): dall' analisi al contesto. Problematicità e nuove prospettive / Langobardske ploče "Mavioranove propovjedaonice « u Gussagu (Brescia): od analize do konteksta. Problematika i nove perspektive

1: Elaborazione grafica di Laura Chinellato da: Paola Marina De Marchi, Calvisano e la necropoli d' ambito longobardo in località Santi di Sopra. La pianura tra l'Oglio, Mella e Chiese nell'altomedioevo, in: L'Italia centro-settentrionale in età longobarda, Atti del Convegno (Ascoli Piceno, 6-7 ottobre 1995), (a cura di) Lidia Paroli, Firenze, 1997., 377-411, fig. 2 / Ilustraciju iz članka: Paola Marina De Marchi, Calvisano e la necropoli d' ambito longobardo in località Santi di Sopra. La pianura tra l'Oglio, Mella e Chiese nell'altomedioevo, in: L'Italia centro-settentrionale in età longobarda, Atti del Convegno (Ascoli Piceno, 6-7 ottobre 1995), (a cura di) Lidia Paroli, Firenze, 1997., 377-411, 2, grafički obradila Laura Chinellato.

2: Studio Rapuzzi di Brescia

3, 4, 5, 6, 7, 8, 10: Laura Chinellato

9: Bruno Genito, Sasanidi, u: Enciclopedia dell'Arte Medievale, X, Roma, 1999., 381-386.
\end{abstract}

\section{Danko Zelić - Ivan Viđen}

Inventario dela giexia di S. Maria Mazor, de tute le argentarie, aparati deli sazerdoti, insenarii, libri, tapezarie et altre robe (1531.) - najstariji imovnik liturgijske opreme, ruha i paramenata dubrovačke prvostolnice / Inventario dela giexia di S. Maria Mazor, de tute le argentarie, aparati deli sazerdoti, insenarii, libri, tapezarie et altre robe (1531) - the Oldest Extant Inventory of Liturgical Objects, Vestments and Textiles of Dubrovnik Cathedral

1: Danko Zelić

2, 3: Božo Gjukić

\section{Josipa Alviž}

Sudbina kapucina i kapucinskoga hospicija u Herceg Novom u svjetlu novih arhivskih istraživanja / The Capuchins and their Hospice in Herceg Novi in the Light of Recent Archival Research

1, 2: Državni arhiv u Zadru (DAZD) / State Archives in Zadar 3, 5, 6, 8-10, 12: Josipa Alviž

4, 7, 11: Arhitektonski crteži prema nacrtima Direkcije za urbanizam Herceg Novi, urbanistički projekt Stari Grad - Herceg Novi, 1982., voditelj Boris Ilijanić, dipl. ing. arh. Izvor: Državni arhiv Crne Gore - Arhivski odsjek Herceg Novi, za tisak pripremio Ratko Horvat I Architectural drawings made after recording of the Directorate for Urban Planning Herceg Novi, Stari Grad - Herceg Novi urban development project, 1982, project leader Boris Ilijanić, architect. Source: State Archives of Montenegro - Archival Department Herceg Novi, prepared by Ratko Horvat

\section{Bojan Goja}

Kuća Dragičević: prilog poznavanju stambenih kuća u Zadru u 18. stoljeću / The Dragičević House: A Contribution to the Research on the $18^{\text {th }}$-century Houses in Zadar

\section{1-9: Bojan Goja \\ 10: Google Earth}

\section{Petar Puhmajer - Krasanka Majer Jurišić}

Stara gradska vijećnica u Rijeci: povijest sjedišta gradske vlasti od najranijih zapisa do 19. stoljeća / Old Town Hall in Rijeka: History of the City Council Seat from the Earliest Records to the $19^{\text {th }}$ Century

1, 11, 12, 13: Natalija Vasić, Hrvatski restauratorski zavod

2: Silvino Gigante, Storia del comune di Fiume, Fiume, 1913.

3: Österreichische Nationalbibliothek, Cod. 8607, fol. 3r, Fiume 4: Österreichisches Staatsarchiv, Kriegsarchiv, Kartensammlung, sign. AT-OeStA/KA KPS KS G I h,171

5: Matthäus Merian: Topographia provinciae Austriacarum, izdanje 1679.

6: Österreichisches Staatsarchiv, Kriegsarchiv, Kartensammlung, sign. AT-OeStA/KA KPS KS G I h, 175

7a, 7b: Državni arhiv u Rijeci, Gradski magistrat Rijeka, Izdvojeni nacrti, kut. 284

8: Državni arhiv u Rijeci, Tehnički ured grada Rijeke, kut. 161

9: Konzervatorski odjel u Rijeci, fototeka

10, 14: Izradili Petar Puhmajer i Marin Čalušić, Hrvatski restauratorski zavod, 2017.

\section{Sanja Cvetnić}

Dva portreta Beatrice Frankapan (?): rod i red / Two Portraits of Beatrice Frankapan (?): the Family and the Order

1: Ivan Kukuljević Sakcinski, Beatrica Frankapan i njezin rod. Zagreb [s. e. Tiskom Dioničke tiskare], 1885.

2: Adolf Bayer, Markgraf Georg und Beatrix von Frangepan: Georg des Frommen Jugend und erste Ehe, Gesellschaft für Fränkische Geschichte, u: Neujahrsblätter der Gesellschaft für Fränkische Geschichte, Ansbach: Brügel, 19 (1934.)

3: (C) Madrid, Museo Thyssen-Bornemisza

4: () Graz, Universalmuseum Joanneum Schloss Eggenberg \& Alte Galerie

5, 6: ๑ Zagreb, Hrvatski državni arhiv

7: ( ) Klagenfurt, Landesmuseum Kärnten

8: Anton Fritz, Das große Hemma-Buch, 1980.

\section{Júlia Tátrai}

Wiener Hofkünstler und die Zrínyis. Porträts in der Lobkowicz-Sammlung / Bečki dvorski umjetnici i Zrinski. Portreti u Zbirci Lobkowicz 
1: 도 Nelahozeves, Lobkowicz Sammlung, Schloss Nelahozeves / Bridgeman Images

2, 3: () Budapest, Magyar Nemzeti Múzeum (Ungarisches Nationalmuseum)

4: ( ) Trakošćan, Dvorac Trakošćan (Schloss Trakošćan)

5: (C) Nelahozeves, Lobkowicz Sammlung, Schloss Nelahozeves / Bridgeman Images

6: @ Budapest, Magyar Nemzeti Galéria (Ungarische Nationalgalerie)

7: @ Zagreb, Hrvatski državni arhiv (Kroatisches Staatsarchiv)

8: () Nelahozeves, Lobkowicz Sammlung, Schloss Nelahozeves /

Bridgeman Images

9: () Privatbesitz Familie Herberstein

10: () Wien, Kunsthistorisches Museum, Wien

11: () Prag, Lobkowicz Sammlung, Prag / Bridgeman Images

12: ๑ Budapest, Magyar Nemzeti Galéria (Ungarische Nationalgalerie)

\section{Daniel Premerl}

Ivan Tomko Mrnavić and his Coat of Arms: Self-presentation of an Illyrian Noble / Ivan Tomko Mrnavić i njegov grb: samopredstavljanje jednoga ilirskoga plemića

1, 2: Paolo Mofardin, Institute of Art History, Zagreb; Courtesy of the Metropolitan Library, Zagreb / Institut za povijest umjetnosti, Zagreb; Uz dopuštenje Metropolitanske knjižnice, Zagreb

$3,6,14,15,16,17$ : Courtesy of the National and University Library, Zagreb / Uz dopuštenje Nacionalne i sveučilišne knjižnice, Zagreb

4, 5: Paolo Mofardin, Institute of Art History, Zagreb; Courtesy of the Library of the Croatian Academy of Sciences and Arts / Institut za povijest umjetnosti, Zagreb; Uz dopuštenje Knjižnice Hrvatske akademije znanosti i umjetnosti

7, 8: Courtesy of the Research Library Zadar / Uz dopuštenje Znanstvene knjižnice Zadar

9: Fra Stipe Nosić, the Library of the Franciscan Monastery, Dubrovnik / Knjižnica Male braće, Dubrovnik

10: Tomislav Pavičić, City Museum Šibenik / Tomislav Pavičić, Muzej Grada Šibenika

11, 12: Paolo Mofardin, Institute of Art History, Zagreb; Courtesy of the Archdiocesan Archives, Zagreb / Institut za povijest umjetnosti, Zagreb; Uz dopuštenje Nadbiskupijskog arhiva, Zagreb

13: Courtesy of the Archives of the Croatian Academy of Sciences and Arts, Zagreb / Uz dopuštenje Arhiva Hrvatske akademije znanosti i umjetnosti, Zagreb

\section{Ivana Čapeta Rakić}

Ponzonijevih deset slika u svodu glavnog oltara splitske katedrale: razmatranja o stilsko-oblikovnim svojstvima, izvornoj funkciji i ikono- grafsko-ikonološkom aspektu / Ten Paintings by Matteo Ponzoni above the Main Altar of the Split Cathedral: Considerations on Design and Style, the Original Function, and the Iconographic-Iconological Aspect

\section{1, 2: Ivana Čapeta Rakić}

3: Ivana Čapeta Rakić, rekonstrukcija / reconstruction: Vojan Koceić 4: Mirko Pivčević, rekonstrukcija / reconstruction: Vojan Koceić

5: Uz dopuštenje Fondazione Musei Civici di Venezia / Courtesy of the Fondazione Musei Civici di Venezia

6: Fotografija preuzeta sa službene web stranice muzeja www.museunacional.cat, uz dopuštenje za preuzimanje i objavu fotografije od muzeja Museu Nacional d'Art de Catalunya / Photo from the official website of the museum, www.museunacional.cat (courtesy of the Museu Nacional d'Art de Catalunya)

\section{Renata Komič Marn}

Saint Joseph and Baby Jesus by Valentin Metzinger and Other Paintings from the Strahl Collection in the Museum of Arts and Crafts in Zagreb / Slika Sveti Josip s malim Isusom Valentina Metzingera $i$ druge slike iz Zbirke Strahl u Muzeju za umjetnost i obrt u Zagrebu

1, 3-6: Srećko Budek i Vedran Benović, Muzej za umjetnost i obrt / Museum of Arts and Crafts, Zagreb, digitalne snimke predmeta iz muzejskog fundusa

2: Ljudevit Griesbach, HAZU, Strossmayerova galerija starih majstora, Zagreb / Croatian Academy of Sciences and Arts, Strossmayer Gallery of Old Masters, Zagreb

\section{Jasminka Najcer Sabljak}

Prizori iz Slavonije i Srijema u opusu austrijskog slikara Franza Alta I Scenes from Slavonia and Syrmia in the Opus of Austrian Painter Franz Alt

\section{1, 9: Georg Eltz}

2, 4-8: Francisca Clary-Aldringen

3: Arhiv Zavičajnog muzeja Ruma / Archive of the Ruma County Museum

\section{Ana Šeparović}

Od »sinteze likovnih umjetnosti« do Zagrebačkoga salona: prilog poznavanju djelovanja ULUH-a 1960-ih / From a "Synthesis of Visual Arts" to the Zagreb Salon: A Contribution to the Research on ULUH's Activity in the 1960s

1: Socijalizam i modernost, katalog izložbe, Zagreb, 2012., 141. 